\title{
An Exploratory Study on the Distribution and Marketing Changes Under the North Korean System
}

\author{
Won-Jun LEE ${ }^{1}$ \\ Received: January 07, 2020. Revised: April 20, 2020. Accepted: May 05, 2020.
}

\begin{abstract}
Purpose: North Korea is a very close country geographically and culturally, but the nation has been one of the most secretive countries in the world. However, in recent years, North Korean society has been known to rapidly change its economic environment as well as its diplomatic and political environment. Since the gaining power of Jong-un, Kim in 2012, the North Korean government has implemented a new set of economic policies. North Korea has embraced limited market systems and mechanisms that have become a part of the formal planned economy. This study is concerned with the recent changes in the market and marketing activities of the communist country. It also seeks to gain an understanding of the changing market behavior of North Korean consumers. The purpose of this study is to enhance understanding of the market environments of North Korea and to provide appropriate implications for practitioners and researchers. Research design, data and methodology: Academic access to information that can understand North Korea's reality is minimal. Therefore, this study was conducted based on a qualitative analysis of secondary data. The existing literature on North Korea, related news and reports were the basis of the analysis. Analysis of secondary data related to North Korea was the main methodology of the study. Results: The official ideology of North Korea rejected most aspects of marketing, and yet there were marketing activities in North Korea. This article focuses on the development of market and marketing activities in North Korea during the recent years. This study indirectly confirmed that the market function is being activated in North Korea, and the basic functions of marketing such as advertisement, price, and distribution are being formed. In this process, the activation of the 'Jangmadang(market)' played a significant role. Conclusions: Research shows that North Korea is rapidly developing its own market function. In addition, marketing activities such as advertising and pricing strategies seem to be unprecedentedly active. However, due to changes in the political environment, the future development of North Korea's marketing is still in flux. Efforts to improve mutual understanding through continuous research are required.
\end{abstract}

Keywords: North Korea, Market, Communist Country, Distribution Economy, Birth of Marketing

JEL Classification Code: M15, M21, M50

\section{Introduction}

북한은 절대권력이 지배하는 전 세계에서 가장 폐쇄적 국가 중 하나이며 지리적, 문화적으로 가장 근접한 한국 사회조차 북한에 대하여 알고 있는 정보와 실상은 사실상 많지 않다(Yoon, 2003). 북한은

\footnotetext{
1 First Author, Professor, Department of Business Administration, Cheongju University, Korea Email: marketing@cju.ac.kr

(c) Copyright: The Author(s)

This is an Open Access article distributed under the terms of the Creative Commons Attribution Non-Commercial License (https://creativecommons.org/licenses/by-nc/4.0/) which permits unrestricted non-commercial use, distribution, and reproduction in any medium, provided the original work is properly cited.
}

분단 이후 장기간에 걸쳐 한국과 민간이나 경제적인 교류가 거의 없었으며 2000 년 초반에 정치적 화해를 기반으로 실행되었던 개성 공단, 금강산 방문 등의 제한적 교류도 2009 년 본격화되기 시작한 미사일 위기 이후로 정치, 군사적 긴장 악화에 따라 지속되지 못하였다(Haggard \& Noland, 2010). 그 결과 한국의 일반인은 물론이고 관련 분야의 연구자들이 북한 사회에 대하여 가지고 있는 이해나 인식은 매우 한정적일 수밖에 없으며 체계적인 연구 역시 활성화되지 못하였다. 특히 북한의 정치적, 군사적 정보나 소식 등은 외신이나 뉴스를 통하여 간헐적으로 알려져 왔지만, 북한 내부의 기업 활동이나 상품, 마케팅 등 상업적 활동에 대해서는 거의 모든 정보들이 여전히 비밀 속에 가려진 실정이다. 
그러나 최근 북한 사회는 외교 및 정치적 환경 변화와 더불어 내부의 경제적 상황 역시 빠르게 변화하고 있으며, 경제 개방의 길을 걷고 있는 것으로 보인다(Haggard \& Noland, 2010; Silberstein, 2019). 과거 북한은 정체된 경제 성장과 기업가에 대한 적대시 정책을 수행하는 '실패 국가(failed economy)'로 서방세계에 인식되어 왔다(zatt, 2010). 그러나 김정은의 2012 년 집권이후 북한은 새로운 경제 정책을 시행하고 있으며, 집단 농장과 정부 소유의 기업 일변도였던 과거의 경제정책을 완화하며 새로운 변화 노력도 보이고 있다(Gray \& Lee, 2015; Lankov, 2015), 2015 년 개정된 소위 '기업소법' 제 39 조에서는 생산물의 가격 재정 및 상품 판매를 공식화하고 기업활동의 이윤 보장을 공식화하였다. 이에 따라 북한에서는 최근 상업 자본을 형성하고 사업 운영비용을 제공하는 집단인 '돈주'들이 등장하고, '장마당'으로 대표되는 사적인 경제 활동이 두드러지고 있는 것으로 알려졌다(Hastings, 2016, Wainwight, Kibler, Heikkila, \& Down, 2018). 개인화된 미디어인 스마트폰 역시 그 보급 대수가 600 만대 이상으로 증가하였고, 이동통신 지역이 전 국토의 $94 \%$ 이상을 커버하게 됨에 따라(Kim, 2014), 스마트폰에 적합한 모바일 광고의 제작 등도 병행되고 있다고 한다(Tudor \& Pearson, 2015). 여전히 은둔의 국가인 북한 사회에 시장의 등장과 사경제의 확산, 마케팅적인 활동의 도입은 주목할 만한 현상이라고 할 수 있으며 점차 북한 특유의 폐쇄적 사회주의 원리에서 벗어나 개인적, 자율적 활동이 경제 영역까지 확장할 가능성이 보이고 있다(Wainwight et al, 2018).

기존 연구에서 제시하듯이 북한 사회에서 시장의 활성화, 사경제의 본격적인 등장은 북한 사회 내부를 변화시키는 동력이 되고 있다. 국영 기업의 통제에서 벗어난 개인 간 시장 거래가 증가하고 있으며, 택시나 운송사업자 등 경제 주체로서 개인사업자의 확대, 사유재산의 축적, 사적인 근로계약 증가가 가져온 고용 관계의 변화, 국영기업의 점증적인 상업화 활동 증가 등이 언론 등을 통하여 보고되고 있는데, 북한 당국 역시 과거와 달리 이를 전면적으로 제한하고 제재하기 보다는 경제적 실리 취득을 위하여 시장과 사경제를 적정선에서 관리, 허용하는 포용적 정책 기조를 유지하고 있는 것으로 알려졌다(Tudor \& Pearson, 2015). 특히 남북한 간 교류와 협력을 통하여 평화를 구가하고, 새로운 경제 성장의 돌파구를 마련하려는 한국 사회의 정치적, 경제적 요구가 증대하면서 북한 사회의 시장 활동과 사적인 이익 추구 활동에 대한 이해의 필요성은 급격하게 증대하였다. 아직은 실현가능한 미래 시점을 예측하기 힘든 단순한 가능성에 대한 타진이지만 개성 공단의 재개나 국제 사회의 북한 내 투자 기회 등에 대한 논의가 차차 다시 시작되고 있으며, 북한 진출을 통한 저렴한 인건비 활용과 새로운 소비시장 판로 개척에 대한 국내외 기업의 관심도 점차 확대되고 있는 실정이다.

그러나 여전히 기업인들에게 북한은 그 자체로서 상상하기 어려울 정도의 불확실성(uncertainty)의 집합체이며, 의사 결정상의 불확실성은 북한에 대한 기업인들의 두려움을 증폭시킨다. 이는 북한 사회의
폐쇄성이 가장 큰 원인이며 부분적으로는 내부에 대한 정확한 통계 자료나 참조할 만한 각종 자료의 부족, 관련된 신뢰할 만한 학술적 연구의 절대적 부족에 귀인하고 있다. 북한 내부 경제 상황에 대한 자료나 판단은 뉴스와 외신을 통하여 파편적으로 수집되고 있지만 그 내용이나 정보의 가치에 대해서는 외부 관찰자나 연구자들 사이에서도 크게 견해가 엇갈리며 일치되지 못하고 있는 실정이다. Curan and Gibson(2019)은 북한에 대한 미국의 신문 기사에 대한 콘텐츠 분석을 통하여 북한에 대한 뉴스조차 상호모순적인 경우가 많고, 내용이 객관적이지 못함을 주장하였다.

이처럼 북한에 대한 뉴스나 통계치는 대부분 신뢰하기 어렵다는 것이 관련 연구자들의 공통적 시각이며(Curan \& Gibson, 2019), 가장 기본적인 통계 지표인 GDP 에 대한 분석결과도 신뢰하기 어렵다(Hastings, 2016). 과거 1991 년에서 1999 년 북한의 GDP 는 37.6\% 역성장을 하였으며, 2000 년대 민간부문의 생산은 1990 년대의 절반에도 채 미치지 못했던 것으로 알려져 있다(Lankov, 2015). 반면에 Lankov(2016)은 북한의 GDP 성장률은 크게 확대되고 있는 시장경제나 지하경제 등을 제대로 반영하지 못하여 상대적으로 과소평가되고 있을 가능성을 제기하고도 하였다.

남북 간 경제적 협력이 국가적 의제로 등장하고 새로운 시장 기회가 기대되는 시점에서 북한의 경제적 실체에 대한 이해 부족과 혼란은 대북 투자나 진출에 관심이 있는 기업의 불확실성을 고조하고 있다. 이런 시대적 요구와 실태 간의 격차는 상호 이해에 부정적 영향을 미치며, 향후 가능한 미래 시나리오인 통일 한국에서 한국이 부담해야 되는 잠재적 통일 비용을 증대시킬 수도 있다. 따라서 북한의 경제적 측면에 대한 올바른 이해를 바탕으로 북한의 기업과 시장, 소비자의 변화를 이해하고, 이들 간의 관계를 기반으로 마케팅 활동이 어떠한 형태로 발현, 진화하고 있는지를 파악하는 것은 중요하다.

이에 본 연구는 최근에 북한에서 활발하게 벌어지고 있는 사경제 유통 활동의 주축인 '장마당'의 형성 과정과 알려진 광고 등 다양한 마케팅 활동의 특성을 기존의 제한적인 연구 문헌과 공개된 정보 원천들을 통하여 확인하고, 실제로 북한 사회에서 진행되는 마케팅 활동에 대한 이해를 넓히고자 한다. 이런 탐험적 연구의 진행은 마케팅을 연구하는 학계는 물론이고, 기업, 그리고 정부의 정책 담당자 모두에게 중요한 시사점을 제공할 수 있을 것이다.

\section{Literature Review}

마케팅은 기업의 이익추구 활동이 보장되는 서구의 자본주의 환경 하에서 출발하였다. 마케팅은 자본주의 사회의 결정체이다. 그 결과, 관련 마케팅 연구자들은 폐쇄적이며 자본주의에 적대적인 공산주의 정권 하에서 실질적인 마케팅 활동은 존재조차 하지 않을 것이라고 
속단하기 쉽다. 일 예로 과거 공산주의 시절 소련에서의 제품 차별화와 광고에 대하여 연구한 Goldman(1960)은 공산주의는 마케팅의 기본인 제품 차별화나 유통 효율성에 대한 노력이 현저하게 부족하다고 주장하였는데, 북한 사회에 대한 한국 혹은 서구의 마케팅 연구자들 시각 역시 과거와 크게 다르지 않을 것이다.

이러한 인식의 배경에는 계획 경제가 주축이 되는 공산주의 사회에서는 소비재 상품은 시장이나 소비자의 요구와는 비교적 무관하게 생산되고, 공급되는 상품 역시 경쟁을 고려한 양질의 상품이라기 보다는 공장이 만들어낼 수 있는 상품을 일방적으로 공급할 것이라는 인식이 자리잡고 있다(Goldman, 1960; Goldman, 1963). 즉, 서구 자본주의 사회에서 마케팅 철학(marketing philosophy)의 변천 과정은 생산 컨셉, 제품 컨셉, 판매 컨셉, 그리고 그 이후 단계로 마케팅 컨셉과 사회적 마케팅 컨셉으로 단계적으로 발전해왔으나(Koter, 2012), 독재 공산주의 국가인 북한은 국가가 주도하는 계획경제의 생산이 수요를 만족시키지 못하고 있을 것으로 추정된다(Lankov 2015). 언론과 방송에서는 제한된 정보원을 기반으로 북한의 빈곤과 고난 등 부정적 기사들을 위주로 방영하였으며(Curan \& Gibson, 2019), 평양이나 개성 등 과거 북한을 다녀온 소수의 관광객들도 평양을 제외한 지방 도시들이 이런 현실과 크게 다르지 않음을 증언하고 있기 때문이다.

과거 남북과 북미 간 대치와 긴장 수준이 현재보다 월등하게 높았을 때, 북한의 빈곤을 알리는 것은 한국과 자유주의의 체제 우수성을 홍보하는 효과적인 정책 수단이었다. 그러나 최근 군사적 긴장 완화와 정치적 화해의 노력이 지속되면서 북한 사회의 다양한 일면을 들여다보고 이해하려는 노력이 증가하고 있다(Emst \& Jurowetki, 2015; Grey \& Lee, 2015; Bonner, 2017; Hastings, 2017; Nam 2017; Xiang, 2019).

특히 반자본주의적 마르크스(Marx) 사상과 외세에 대한 거부감이 높은 북한 사회에서 기업과 마케팅 활동이 존재할 것인가도 이런 관심의 한 부분이다. 비록 공산주의 국가들이 공식적으로는 기업의 이윤추구 활동이나 상품의 유통이나 마케팅을 사회의 악(evils)으로 치부하고 있음에도 불구하고 마케팅이 추구하는 상품의 개발, 유통, 가격의 책정. 홍보 등 마케팅 $4 \mathrm{P}$ 의 주요한 기능들은 사회 유지를 위하여 필수적으로 필요한 기능이기 때문에 어떠한 형태로든 존재할 수밖에 없다Fox, Skorobogatykj, \& Saginova, 2005).

일 예로 기밀이 해제된 행정 문서와 자료들을 기반으로 공산주의 국가였던 러시아(구: 소비에트 공화국)와 동구권 국가들이 과거 공산주의 체제하에서 어떤 마케팅 활동이 이루어졌는지에 대하여 접근한 이론적 연구 성과들이 있다. Goldman(1963)과 Greer(1973)와 같은 초기 연구자들은 소비에트 공화국이 공개한 문서, 신문, 잡지, 그리고 짧은 현지 방문을 통하여 소비에트 체제 하의 마케팅 시스템의 구성 방식과 운영 원리를 연구하였다. Felker(1966)는 소비에트 공화국을 방문하여 문헌 조사와 현지인 인터뷰를 진행한 이후, 공산정권의 통제가 철저하였던 당시 사회에서도 물류, 창고, 생산 등 마케팅의
필수적 기능들은 이미 상당 수준 구축되었으며, 소비자와 니즈와 선호도를 고려한 생산도 증대하는 마케팅 변화기가 도래하고 있음을 확인한 바 있다. 소비에트 공화국의 존속기간(1961 1991) 동안의 변화를 연구한 Fox et al.(2005)의 주장에 따르면 소비에트 정권의 말기에는 정부의 효율적 정책 수행, 무역의 활성화, 지방분권화의 확산 등의 외부 요인으로 마케팅의 중요성이 강화되었으며 관련하여 공개적인 마케팅 관련 교육도 활성화되었다고 한다.

따라서 북한사회 역시 이념적으로 다른 프레임(frame)이나 대안적 접근 방식을 택할 수는 있지만 기본적인 마케팅 개념과 활동은 내부적으로는 존속하여 발전하여 왔을 것이라는 주장이 등장하고 있다(Wainwight et al, 2018). 북한은 수출을 통한 외화벌이가 정권 및 국내 경제 유지의 주요한 수단이기 때문에 해외 시장을 고려한 마케팅 활동은 장기간에 걸쳐 존재하여 왔을 것이다. 이러한 가능성에도 불구하고 자유로운 방문이 제한된 폐쇄국가인 북한의 마케팅 활동에 대한 연구는 거의 존재하지 않는 것이 사실이며, 북한의 마케팅 활동 현황을 직간접적으로 이해할 수 있는 선행 연구도 제한적이다. 이에 본 연구에서는 북한 사회 내부에서도 마케팅의 전제조건이라고 할 수 있는 시장화(marketization)와 광고 등 다양한 마케팅 활동이 일반적인 예상 수준 이상으로 진행되었을 가능성이 있었음을 가정하며, 북한의 시장화 현상과 마케팅 활동의 확산 현상을 기존의 문헌을 중심으로 차례로 고찰하고자 한다.

북한 역시 공신력 있는 공식 통계나 내부 자료는 여전히 발표하고 있지 않아 연구자의 어려움을 가중시키고 있으며, 사실상 연구자의 자유로운 방문이 불가능하다는 점에서 북한의 마케팅을 이해하는 것은 매우 과제이다. 그러나 현 시점에서 북한에 대한 직접적 방문이나 1 차적 자료 접근가능성은 매우 희박하지만, '근로자'나 '경제연구'와 같이 북한이 자체적으로 발간하는 경제 전문지와 공개하는 인터넷 정보 등 한국에서도 접근가능한 2 차 정보원들을 통해서 자신들의 경제 관련 이슈들에 대한 주장을 펼쳐오고 있다. 북한이 발간하는 '경제연구'는 1956 년 4 월 10 일 창간된 후 계간지 형태로 발간되고 있으며, 북한의 주장에 의하면 북한 경제학 부문에서 이룩된 연구 성과들을 체계적으로 종합하여 반영하고 있는데, 이런 자료들은 북한의 유통과 마케팅을 이해하는데 큰 도움을 줄 수 있을 것이다.

\section{Literature Analysis}

\subsection{Marketization of North Korea}

아담 스미스가 주장한 보이지 않는 손(invisible hand)의 역할이 강조된 이래 자본주의 사회에서 시장의 기능은 항상 필수적인 요소였으며 시장에서의 활동을 중심으로 연구하는 마케팅은 20 세기 이후 그 
중요성이 더욱 강조되어 왔다. 현대 경제 시스템에서 시장과 마케팅은 주어진 역할을 소화하며 거래의 효용 증가, 고객의 가치 증대, 거래의 안전성 강화 등 부가적인 가치를 창출하여 왔다. 계획 경제(PDS: public distribution system)가 경제의 원칙이며, 시장의 존재가 부정되어오던 북한도 예외일 수는 없으며, 북한 정부의 허가를 받지 못한 암시장(black market)이 암묵적으로 형성되고 운영되어 왔다. 암시장은 전체 상품 보급의 $60 \%$ 이상을 차지하던 경직된 북한의 국가 보급 체제의 문제점을 보완하면서 활성화되었는데, 전체 주민의 최소 $20 \%$ 이상은 직간접적으로 암시장에 의존하여 왔으며, 북한 주민의 $72 \%$ 는 암시장을 통하여 추가적 수입을 획득하였다고 한다(Xiang, 2019).

그러나 과거 엄격한 공산주의 체제 하에서 시장과 시장 내 관련 활동은 존재 의의를 인정받지 못하였으며, 철폐하여야 할 사회적 적폐로 치부되기도 하였다. 여전히 폐쇄적 국가인 북한 역시 예외는 아니며, 북한 정부의 시장에 대한 기본적인 인식은 매우 적대적이다. 이를 단적으로 보여주는 2004 년도 북한 노동당 중앙위원회의 정책적 지시문에 의하면, '시장은 인민들에게 생활상 편의를 주는 장소가 아니라 국가 규률과 사회질서를 문란케 하는 장소 또는 장사군들이 상품가격을 올리고 폭리를 얻는 돈벌이 장소'에 불과하다고 인식되어 왔으며, 그 결과 철폐가 마땅한 사회적 죄악으로 치부되었다(Lankov \& $\mathrm{Kim}, 2008)$.

그럼에도 불구하고, 시장의 기본적인 교환 및 거래 기능에 대한 일반 북한 주민, 즉 북한 소비자들의 요구는 지속적으로 존재하여 왔으며, 북한 사회에서 자생적인 자본주의의 존재가 감지되고 있는데, 이는 국가 주도의 경제가 한계를 보이고 북한 정부의 통제력이 한계점에 도달하고 있음을 보여준다(Lankov \& Kim, 2008; Lankov, 2015). 특히 소련 연방이 붕괴한 이후부터 북한 경제는 깊은 침체의 수렁에 빠져들게 되었고, '고난의 행군'이라는 전례 없는 기근을 겪으면서 이념보다 실리를 추구하게 되었다는 분석이 유력하다(Haggard \& Noland, 2010). 냉전이 해체되면서, 국가의 경제적 존립에 대한 위기의식이 변화의 시발점이 되었다(Hastings, 2016).

이에 북한은 2000 년대 이후에는 계획경제와 시장이 공존하는 형태의 혼합적 형태의 사회주의 경제로 변모하였는데, 특히 김정은 정권이 전면적으로 등장한 이후에는 사실상 사회주의적 계획경제 자체가 과거의 의미를 상실하고 있으며, 경화(hard currency)인 달러화가 주된 거래 수단으로 통용되는 시장이 경제의 핵심 중추를 담당하는 시장경제적 특색이 강화되고 있는 것으로 알려졌다(Kim, 2014).

오늘날 북한에서는 흔히 시장은 마켓(market)을 순 한글로 풀어 쓴 이름인 '장마당, 혹은 '개구리 시장'으로 통칭하고 있는데, 농산품, 식료품, 생필품 등 판매하는 상품의 종류 증가와 더불어 도시와 농촌을 가리지 않고 북한 전역에 걸쳐 빠르게 급증하고 있다. 개구리 시장이라는 명칭은 정부의 단속이 나오면 장을 거두어들이고 도망가는 모습이 마치 개구리와 유사해서 붙여진 명칭이라고 한다Xiang, 2019). 그러나, 이런
북한 정부의 단속에도 불구하고 장마당은 계속 증가하고 있다고 한다. 장마당은 북한의 시장화가 정부 주도가 아니라 민간 영역에서 자발적으로 시작되었음을 의미한다. 남한에 거주하는 탈북민 300 명 대상의 설문조사에 따르면, 북한 주민들은 통상적인 직장 업무 외에 부업을 하는 것이 일반화되어 있으며, 응답자중의 $15 \%$ 는 장마당에서 장사를 한 경험이 있다고 응답하였다(Haggard \& Noland, 2010).

이를 입증하듯, 미국의 존스 홉킨스 대학의 연구진들이 입수 가능한 위성사진을 판독하여 조사한 자료에 의하면 2009 년 북한의 상설 시장 수는 200 개 내외로 추산되었으나, 2015 년 다시 분석한 재조사에서는 그 두 배 이상인 400 개 내외가 될 것으로 예측되었다(Emist \& Jurowetzki, 2016. 단 기간에 시장의 숫자가 두배 이상 증대한 것은 사경제인 시장의 역할이 확대되고 있음을 의미한다. 또한 이와 같은 시장의 양적 성장과 더불어 그 내실도 변화하고 있는 것으로 알려지고 있는데, 시장에서 상품을 판매하는 매대(shelf)의 크기가 커지거나 창고, 주차장 등 전에 없던 새로운 고객 편의시설이나 마케팅 지원 시설물들이 증가하고 있는 것으로 알려지고 있다. 또한 일반적인 자본주의 사회의 점포나 매점의 소유권을 거래하는 것과 마찬가지로 시장의 매대 역시 일종의 사유재산으로 인식되고 있으며 권리금이 부가된 후 소유권 이전 등의 거래가 이루어진다고 한다. 시장의 운영에 필요한 인프라와 부가 서비스는 성공적 시장의 전제 조건이므로(Nam, 2017), 관련된 기반 시설 역시 빠르게 형성되고 있을 것으로 예측된다.

이와 같은 시장의 구조적 변화와 새로운 운영 방식의 등장은 폐쇄적이었던 북한 사회 내부에서 민간 주도의 본격적인 시장과 유통구조가 형성되고 있으며, 그 시장에서의 활동, 즉 시장화(marketization)와 마케팅이 동시다발적으로 태동하고 있음을 보여준다. 특히 남북 간 경제 교류의 가능성 타진과 협력 노력이 증대하고 있는 시점에서 이런 변화는 중대한 의의를 지닌다. 시장화의 확산이 북한 주민이나 사회에 미치는 중요한 영향은 자본주의에 대한 적대감이나 부정적 인식이 상당부분 완화되고 있다는 점이며, 외부 경제에 대한 포용력도 증대하고 있다는 점이다. 개인이 주체가 되는 상거래 행위가 증대하고 이를 통한 본격적인 이윤 추구 활동이 일상화되기 시작하면서 과거의 집단주의적 생활양식과 국가 의존적 의식은 점차 희석되고 있으며, 독자 생존 의식, 실적주의, 개인 영리 주인 등이 주민들에게 자리잡게 된 것이다.

\subsection{The Advent of Marketing}

비교적 최근까지 북한은 '인민의 리익을 침해하는 비사회주의적 행위를 저지하자'며 가격 상한선을 설정하고, 식량 전매제를 통하여 시장에 대한 검열과 단속을 강화하였음을 고려할 때, 여전히 북한 사회에서 본격적인 마케팅 활동은 불법적이며 위험한 활동이었다. 그러나 최근에는 시장화의 급속한 진전과 관련하여 학교에서의 상업적 
활동에 대한 교육이 제공되고 있으며(Tudor \& Pearson, 2015), 시장에서의 활동, 즉 초기 마케팅 활동이 등장하고 있다(Emsr \& Jurowetki, 2015; Lankov, 2015; Tudor \& Pearson, 2015). 실제로 장마당에서 상인들 간의 경쟁이 치열해짐에 따라 이들의 상업적 활동도 다양하게 변화하고 있는데(Lankov, 2015), 저렴한 가격을 바탕으로 판매량을 증대시키려는 박리다매 전략, 덤으로 제공하는 미끼 상품 제공, 추가적인 가격 할인 제공 등 전에 없던 가격 정책, 촉진 전략 등 다양한 판매 전략과 상술이 속속 등장하고 있으며, 암시장의 상인 간에 서로 권리와 이익을 보호하기 위한 일종의 유통업자 조합인 상인 동맹이 자생적으로 형성되고 있다고 한다(Chestnut, 2007; Lankov \& Kim, 2008). 또한 북한의 상류층에서는 자신의 사회적 지위와 부를 대물림하기 위하여 자녀들에게 상업 관련 교육과 기업가 역량을 강화하는 교육이 인기를 끌고 있다고 한다 (Pearson, 2015).

이러한 실질적인 마케팅에 대한 관심 증대와 초기 마케팅 활동의 증대 배경에는 김정은 체제의 출범 이후 변화된 북한 정부의 완화된 입장이 존재한다. 현재 북한 정권은 주민들의 시장 활동에 대한 과도한 통제를 가하지 않고 있는 동시에 여전히 국가의 영향력이 강력하게 미치고 있는 국영 기업의 생산 활동에도 시장경제적 요소를 속속 도입하고 있다(Kim. 2006). 그 결과, 국가 주도의 생산 계획은 축소되고 있으며, 기업 자율에 따른 비계획 생산 비중은 역으로 증가하고 있다. 최근 국가의 계획관리 체계가 붕괴하기 시작하면서 국가 계획에 의한 생산은 감소하고 있으며, 생산의 자율성은 시장 수익성이 높은 품목을 중심으로 우선 생산하는 시장지향적인 경향이 등장한 것이다. 즉, 북한 기업들은 일단 국가가 부여한 계획과 품목에 따라 생산을 완수하고 나면, 여분의 생산 능력은 시장 수요가 많은 제품을 중심으로 수익 창출을 위한 생산 활동을 진행하고 있다. 2000 년대 초반에 시행된 경제관리 개선조치와 종합시장의 개설 이후 일부 국영 기업들은 생산량의 일정 지분을 시장을 통하여 자유롭게 처분할 수 있도록 허용하였다고 한다(Grey \& Lee, 2015).

관련된 정책적 변화는 아직 초기의 시도이지만 그 의의는 매우 크다. 사실상 개인이나 민간이 운영하는 제대로 된 기업이 존재하기 힘든 북한의 특성상 국영 기업의 마케팅에 대한 태도 변화는 북한의 경제 변화를 이해하는 시금석의 역할을 하기 때문이다. 김정은 정권 이후 '새로운 경제관리 개선조치(소위 6. 28 방침)'의 공표를 통하여 공장, 기업소, 농장에 제품의 생산과 판매, 이윤 배분의 자율권을 확대시켜 주고 있으며, 확대된 자율권 속에는 생산 제품의 결정, 시장의 소비자 등 수요 요인의 고려, 시장 공간을 판매처이자 유통 경로로 활용할 수 있게 하고 있다(Park, 2018). 이는 점 등 마케팅 $4 \mathrm{P}$ 의 구성에 필요한 기초적인 요소들이 부분적이지만 일부 포함되고 있는 것이다.

이들 국영 기업에 대한 자율권 부여에는 마케팅 활동의 중요한 핵심 요인인 상품의 차별화도 진전되고 있는 것으로 알려져 있다(Park, 2018). 과거 사회주의 계획경제 하에서는 모든 경제 행위를 국가의 계획이
주도함에 따라 생산과 소비 활동 모두 대규모화, 균질화 되는 것이 당연시되었다. 일 예로, 신발을 생산하는 북한의 국영 기업들은 국가가 제공하는 동질적인 투입 요소를 기반으로 동일한 품질과 디자인의 신발을 대규모로 생산하고, 북한의 소비자들은 별다른 선택의 여지없이 배급을 통하여 이를 일시에 집단적으로 소비시키는 방식이었으며, 상품의 품질은 물론이고, 가격, 소비 시점까지 집단적으로 동질하게 관리되었다. 그러나 현재 북한의 경제는 시장 원리 확산으로 각 경제권역별로 존재하는 다수의 경제 주체들이 자신들만의 의도를 갖고 상대적으로 소규모 소비자들을 대상으로 이질적 투입요소를 통해 제품과 서비스를 제공하는 경우가 확대되고 있으며, 소비자들 역시 이를 차별적, 선택적으로 소비하는 현상이 확대되고 있다. 생산과 소비 양 측에서의 이러한 변화는 점증하는 중국 등 외산 제품의 수입과 더불어 제품과 서비스의 차별화를 촉진하고 있다(Gray \& Lee, 2015; Lankov, 2016.

\subsection{Advertising and Consumer in North Korea}

이처럼 북한의 시장화, 마케팅 개념의 태동은 곳곳에서 감지되고 있으나 외부의 기업인이나 연구자 등에게 직접적으로 확인되기는 어려운 내부적인 변화들이다. 그러나 이러한 마케팅 활동들 중에서도 방송 등 미디어를 매개체로 활용하는 광고나 판촉 활동 등은 비교적 더 다양하고 신속하게 외부로 알려지고 있다(Bonner, 2017). 북한의 광고 활동에 대한 정보가 외부 세계로 노출되는 것은 광고 활동이 TV, 라디오, 신문 등 매체를 통하여 이루어짐에 따라 국경을 접한 인접 국가인 중국의 매체 등을 통하여 지속적으로 확인된다는 점, 그리고 아직 소수이지만 북한을 방문하는 미국, 중국, 일본 등 외국 관광객들을 대상으로 외화 벌이 목적의 광고 활동, 상품 소비 활동이 전개되고 있다는 점에서 그 이유를 찾을 수 있다.

짧은 역사의 북한 광고에 있어서 기념비적인 순간은 2009 년 7 월 $\mathrm{TV}$ 를 통하여 최초로 전파를 탄 대동강 맥주의 광고이다. 대동강 맥주 광고가 획기적인 변화로 인식된 이유는 실질적으로 북한 최초의 상업 광고이기 때문이다(Yoo, Kang, \& Kim, 2019). 사실상 그 이전에는 경제에 대한 철저한 통제와 외부 자본주의적 세력의 침투 우려로 사실상 상업적 광고의 제작이나 광고만을 위한 매체 시간 등은 존재하지 않았으며, 일반적으로 북한의 방송은 광고 시간 없이, 정권에 대한 뉴스, 공장 방문 등 설명, 어린이 만화, 지도자에 대한 일방적인 다큐멘터리로만 구성되어왔다. 이런 상황에서 대동강 맥주의 광고는 자본주의 방식의 광고 개념이 최초로 도입된 사례로 볼 수 있다. 맥주에 이어서 인삼 등 건강 제품과 평양의 대표적 외식공간인 옥류관의 메추리 요리에 대한 광고가 등장함에 따라 외부 세계의 사람들은 이제 북한의 삶에도 본격적인 자본주의적 삶의 방식이 도입되는 것이 아닌가 판단하기도 하였다The North Korea Economy Watch, 2009). 
그러나 다른 장마당 활동이나 마케팅 활동과 마찬가지로 광고 역시 아직 본격화 단계는 아니며 북한 정권의 정책적 필요성에 따라 광고가 허용되거나 제재되기도 하는 등 변화기에 있는 점을 고려해야 한다. 일 예로, 대동강 맥주로 촉발된 대중 광고의 흐름은 결코 오래가지 못했으며 2009 년 8 월말 이후 급격하게 자취를 감추게 되었다. 외신을 통하여 알려진 바에 의하면 TV 를 통해서 광고를 접한 당시 김정일 위원장이 중국식 자본주의의 부정적 영향력의 침투로 광고를 규정하고 광고에 대하여 비난을 강하게 가함에 따라 단 2 개월 만에 북한의 짧은 광고 전성기는 막을 내리게 되었다고 한다. 이후 공식적으로 광고는 다시 전면적으로 부상하지는 못하였고, 그 결과 현재 북한은 별도의 TV 광고 시간을 편성하지 못하고 있는 것으로 알려져 있다(Kim, 2018). 경직된 북한 사회 시스템에서 TV 등 대중 매체는 정부의 핵심적 선전 수단이기 때문에 북한 당국의 직접적인 관리 감독을 받고 있어 광고를 위한 시간이나 시스템 조정 등이 어려운 것이 현실이다. 북한의 방송 매체들은 이른바 주체사상의 확산과 공고화를 목적으로 운영되며 그 특성상 정치적 목적의 선전과 선동 내용이 강하다.

그러나 거래 상품의 증가와 홍보 강화, 북한 주민의 관심 증대에 따라 광고를 방영할 필요성이 증대하면서 북한은 다시 광고에 대하여 변화된 태도를 취하고 있다. 시장이 형성되기 시작하면서 유통 거래가 증가하고 있고, 기업책임관리제 도입, 생산품 판매 자율성 확보 등으로 북한 내 마케팅과 광고에 대한 수요 역시 증가하여 왔다(Tudor \& Pearson, 2015). 또한 최근 알려진 바에 의하면, 북한의 TV 프로그램들도 역시 남녀 간 애정 문제, 주민 생활상의 보도, 그리고 사회적 갈등을 다루는 등 점차 다양화하는 변화를 겪고 있다. 이런 분위기 변화에 편승하여 간접적인 $\mathrm{TV}$ 상품 광고도 다시 등장하고 있는 것으로 알려졌다(Tudor \& Pearson, 2015).

다만, 현재 재개되고 있는 북한의 TV 광고는 한국이나 중국, 혹은 다른 서방 국가들과 다르게 별도의 광고를 위한 특정 시간(time slot)을 배정하고 있지는 않으며, 뉴스를 통한 광고 혹은 다큐멘터리 형태의 광고로 진행된다고 한다. 뉴스의 일부로서 $\mathrm{TV}$ 광고를 시행하는 경우에는 북한 내부 관련 뉴스를 보도한 이후 프로그램 후반부에 별도의 '명산품 소개' 코너를 공익성 광고 형태로 운영하고 있으며, 30 초간 정지화면과 음악을 송출하는 매우 단순한 방식으로 두 개 혹은 세 개 내외의 상품을 광고하는 방식을 사용하고 있다. 주된 광고 상품은 북한이 자체적으로 생산하고 있는 한방약, 화장품, 식품 등 일상적 소비재 중심이나 컴퓨터나 텔레비전 등 생활관련 가전제품의 비중도 빠르게 증가하고 있는 추세이다(North Korean Economy Watch, 2018).

반면에 다큐멘터리 형식을 취한 TV 광고는 보통 5 분내지 10 분가량의 선전 프로그램 형식으로 진행되며, 유통 관련 기업소 및 소비재 공장의 탐방 보도 형태를 취하고 있다. 그러나 과거와 달리 관련 내용에 정치적, 사상적 내용은 거의 배제하고 있으며, 우수한 기술력이나 품질에 대한 광고성 설명을 중심으로 상품 특성을 소개하는 간략한 자막이나
고객들의 사용이나 체험 경험을 중심으로 제공되는 특성이 있다. 특히 기업의 종류와 숫자가 비교적 많지 않기 때문에 광고 역시 소수 기업들로 집중되는 경향이 있는데, 대표적 광고 기업으로는 류경 장미원(오락업종), 미림 승마구락부(오락업종), 고려항공(운수업종) 등 서비스업 광고도 증가하고 있다(Kim, 2018).

Table 1: Type of North Korean Advertising (Kim, 2018)

\begin{tabular}{|c|c|c|c|c|c|}
\hline \multicolumn{3}{|c|}{ (1) News Type } & \multicolumn{3}{|c|}{ (2) Documentary Type } \\
\hline Item & $\begin{array}{c}\text { Cou } \\
\mathrm{nt}\end{array}$ & $\%$ & Item & $\begin{array}{c}\text { Cou } \\
\text { nt }\end{array}$ & $\%$ \\
\hline $\begin{array}{l}\text { Oriental medic } \\
\text { ine }\end{array}$ & 20 & $\begin{array}{l}37 . \\
7 \% \\
\end{array}$ & $\begin{array}{c}\text { Food \& beve } \\
\text { rage }\end{array}$ & 5 & $25 \%$ \\
\hline Electronics & 7 & $\begin{array}{l}13 . \\
2 \% \\
\end{array}$ & Shops & 3 & $15 \%$ \\
\hline Cosmetics & 7 & $\begin{array}{l}13 . \\
2 \%\end{array}$ & Electronics & 2 & $10 \%$ \\
\hline $\begin{array}{c}\text { Food \& bever } \\
\text { age }\end{array}$ & 6 & $\begin{array}{l}11 . \\
3 \%\end{array}$ & Construction & 2 & $10 \%$ \\
\hline Detergent & 3 & $5.7 \%$ & Entertainment & 2 & $10 \%$ \\
\hline Medical $t$ & 2 & $3.8 \%$ & $\begin{array}{l}\text { Oriental medi } \\
\text { cine }\end{array}$ & 2 & $10 \%$ \\
\hline Others & 8 & $\begin{array}{l}15 . \\
1 \%\end{array}$ & Others & 4 & $20 \%$ \\
\hline Total & 53 & $\begin{array}{l}10 \\
0 \%\end{array}$ & Total & 20 & $\begin{array}{l}10 \\
0 \%\end{array}$ \\
\hline
\end{tabular}

\section{Conclusion and Implication}

\subsection{Conclusion}

현재 북한의 시장화와 마케팅 허용에 관한 가장 중요하고 강력한 변수는 북한 정부의 정책이지만, 이를 직접 확인하거나 예측하는 것은 현재로서는 매우 어렵다. 이를 보완하기 위하여 본 연구는 알려진 자료를 기반으로 북한의 경제적 변화를 다각적으로 조명하고, 시사점을 제공하고자 하였다.

첫째, 북한 사회의 변화와 새로운 마케팅의 등장에 대한 이해를 증진하고자 노력하였다. 자료 수집과 접근의 어려움에도 불구하고 북한의 시장, 기업, 소비자, 그리고 마케팅 활동에 대한 이해는 한국의 입장에서는 절대적으로 필요하고 시급한 과업이다. 향후에 기대되는 남북 협력이나 기업의 교류 활동, 대외 원조 형태의 지원이 현실적 국가차원의 전략 이슈로 등장할 수 있으나 우리가 북한 사회나 경제활동에 대하여 알고 있는 것은 거의 전무한 실정이다. 일부 연구자들은 북한의 시장 개혁과 경제 정책이 중국을 모방하고 있다고 주장하기도 하나, 그 진행속도와 양상은 중국과 차이가 있다(Gray \& Lee, 2015). 이런 예측 불가능한 위험과 불확실성은 협력을 저해할 수 있기 
때문이다. 또한 북한 사회와 경제, 시장에 대한 바른 이해는 미래에 지불해야 되는 잠재적 통일 비용의 감소에 도움을 줄 수 있다.

둘째, 지속적인 북한 사회 내 경제 활동에 관한 연구의 필요성을 주장하였다. 한국은 지정학적인 위치나 사회적 여건상 북한에 대하여 비교적 정확한 정보를 수집하고 연구를 진행할 수 있는 장점을 가지고 있다. 비록 연구 목적이라도 아직까지는 연구자가 직접 북한을 방문할 수는 없으나 인접한 중국이라는 창을 통하여 북한 사회를 살펴볼 기회가 있다. 북-중 접경 지역에서는 일부 북한의 상품이나 시장 정보 접근이 가능하며, 북한을 방문하는 중국인 관광객들을 통한 간접적 연구가 가능하다. 또한 북한사회를 떠난 다수의 탈북민들이 대부분 한국을 새로운 정착지로 선택하고 있으며, 이들의 한국내 성공적인 정착에도 본 연구를 통한 북한 사회 이해는 도움이 될 수 있을 것이다. 통일부가 2018 년 공개한 통계자료에 의하면, 2018 년 3 월 기준 탈북주민의 숫자는 이미 누적 32,000 명을 넘어섰으며, 이들에 대한 이해는 사회 통합의 주요한 이슈가 되고 있다. 북한 사회에 대한 지속적인 관심과 연구는 향후 미래의 통일 체제에 대한 준비가 될 뿐만 아니라 국내 정착 후 한국 사회에 대하여 이질감을 느끼고 있는 탈북 주민의 사회적 통합에도 도움이 될 것이다(Lankov, 2015).

셋째, 본 연구 결과는 향후 북한 시장과 소비자에 관심이 있는 국내외 기업들에게 북한 소비자를 이해하고 적절한 마케팅 전략을 수립하는 기초가 될 수 있을 것이다. 문화와 사회 시스템에 대한 상호 이해는 통합에 필수적인 전제조건이다(Kim, 2017). 또한 동아시아 지역의 미래 시장 주도권을 놓고 한중, 한일간 갈등도 첨예해지고 있으며(Kim, 2007), 소비 시장과 생산 거점으로서 북한의 중요성도 증대하고 있다. 이에 현재까지 수집 가능한 자료들을 바탕으로 다소나마 정보의 불확실성이 가져오는 위험을 감소시키고, 향후 장마당 등 유통과 광고의 발전 방향을 가늠할 수 있으며, 이를 바탕으로 한국 기업의 북한 시장 협력 등 미래 시나리오의 구축과 적용이 가능할 것으로 기대한다.

넷째, 북한의 시장화가 가져올 잠재적 위기와 기회 요인에 대하여 기업의 이해관계자들이 고려할 기회를 제공하였다. Lankov(2016)의 주장에 의하면 북한의 경제적 개방은 정치적 자유화에 대한 주민의 욕구를 자극할 수 있고, 심화되는 북한 주민간의 소득 불평등은 북한 체제를 불안정하게 만드는 요인이 될 수 있다고 한다. 본 연구를 기반으로 향후 북한의 시장 변화가 불러올 가상 시나리오를 구축하고 대비하는 노력이 필요할 것으로 판단된다.

\subsection{Limitations and Further Research}

북한 사회에 대한 연구들은 정치적 관점에서 일부 학술적 연구가 이루어지고는 있으나 북한 사회의 폐쇄성만큼 국내는 물론이고 해외에서도 매우 희소하며, 향후에도 관련 연구의 활성화나 확대에는 큰 난관이 존재한다. 이에 따라 북한의 기업인이나 기업, 시장과 마케팅
개념의 등장과 실태, 현황에 관한 연구는 사실상 전무한 수준이라고 판단된다. 본 연구 역시 이러한 어려움으로부터 결코 자유롭지 못하며, 북한 관련 연구는 연구에 필요한 신뢰성 있는 기초 통계자료의 추가적인 확보, 연구 대상에 대한 방문이나 접근성 제약의 문제 해결, 필요한 데이터 수집의 어려움 등은 향후 연구들이 극복해야할 과제이다. 향후 연구의 확장을 위해서는 공개된 다양한 정부 문서, 신문, 발표문 등 다양한 2 차 자료를 지속적으로 수집하여 분석하고, 방문 경험이 있는 국내외 관광객들을 통한 인터뷰 등 직접적 1 차 자료를 수집해야 할 것이다. 참조할 만한 방법론으로서, 과거 서방사회의 연구자들인 Goldman(1963)과 Greer(1973)등과 같은 초기 연구자들이 당시 폐쇄적 독재, 공산국가였던 소비에트 공화국이 공개한 문서, 신문, 잡지, 그리고 짧은 현지 방문을 통하여 소비에트 체제하의 마케팅 시스템의 구성 방식과 운영 원리를 연구한 방식을 참조할 수 있다. 본 연구도 현재로서는 다양한 자료 수집에는 큰 장벽이 존재하지만 추가적인 비공개 정보원천을 통하여 다양한 문헌자료를 우선적으로 수집할 필요가 있으며, 북한사회 전문가 집단의 인터뷰와 더불어 한국 사회에 정착한 탈북주민의 경험 인터뷰 등 추가적 노력이 필요할 것이다. 또한 향후 남북한 관광 등 민간인 교류가 가능하여 직접 방문이 자료 수집이 가능한 시대가 도래될 경우에는 Johnson and Onmuegbuzie(2004)나 Creswell and Clark(2017)가 제시한 복합적 방법론(mixed method)의 사용과 자료 수집 노력이 요구될 것이다.

\section{References}

Bonner, N. (2017). Made in North Korea. New York, NY: Phaidon Press.

Burchill, G., \& Fine, C. H. (1997). Time versus market orientation in product concept development: Empiricaly-based theory generation. Management Science, 43(4), 465-478.

Chestnut, S. (2007). Illicit activity and proliferation: North Korean smuggling networks. International Security, 32(1), 80-111.

Creswell, J. W., \& Clark, V. L. P. (2017). Designing and Conducting Mixed Methods Research. Thousand Oaks, CA: Sage Publications.

Curan, N. M., \& Gibson, J. (2019). Conflict and responsibility: Content analysis of American news media organizations' framing of North Korea. Media War \& Conflict, 1-19.

Ernist, M., \& Jurowetzki, R. (2016). Satellite data, women defectors and black markets in North Korea: A quantitative study of the North Korean informal sector using night-time lights satellite imagery. North Korean Review, 12(2), 64-83.

Felker, J. L. (1966). Soviet Economic Controversies: The Emerging Marketing Concept and Changes in Planning (pp.1960-1965). Cambridge, MA: M.I.T. Press.

Fox, K. F. A., Skorobogatykh, I. I., \& Saginova, O. V. (2005). The Soviet evolution of marketing thought, 1961-1991: from Marx to marketing. Marketing Theory, 5(3), 283-307.

Giddens, A. (1984). The Constitution of Society. Berkeley, CA: 
The University of California Press.

Goldman, M. (1960). Product differentiation and advertising: Some lessons from Soviet experience. Journal of Political Economy, 68(4), 346-357.

Goldman, M. (1963). Soviet Marketing: Distribution in a Controlled Economy. New York, NY: The Free Press of Glencoe.

Gray, K., \& Lee, J-W. (2015). Following in China's footsteps? The political economy of North Korean reform. The Pacific Review, 1-25.

Greer, T. (1973). Marketing in the Soviet Union. New York, NY: Praeger.

Haggard, S., \& Noland, M. (2010). Sanctioning North Korea: The political economy of denuclearization and proliferation. Asian Survey, 50(3), 539-568.

Hastings, J. V. (2016). A most enterprising country: North Korea in the global economy. Ithaca, NY: Cornell University Press.

Izatt, H. (2010). Can North Korea develop? Developmental dictatorship versus the China reform model. Asian Politics \& Policy, 2(2), 175-195.

Johnson, R. B., \& Onwuegbuzie, A. J. (2004). Mixed methods research: A research paradigm whose time has come. Educational Researcher, 33(7), 14-26.

Kim, H. S. (2007), A study on the competitive status and cooperative schemes of Korea-China ports. Journal of Distribution Science, 5(2), 55-78.

Kim, J. C. (2006). The political economy of Chinese investment in North Korea. Asian Survey, 49(6), 898-916.

Kim, J. J. (2017). A study on the consciousness for KoreanChinese Adaptation in Korea. International Journal of Industrial Distribution \& Business, 8(4), 7-13.

Kim, M. K. (2018, May 28). North Korea's TV Ad Usage and Implications (pp.12-23). Weekly KDB Report.

Kim, Y. (2014). Cell phones in North Korea. US-Korea Institute at SAIS.

Kotler, P. (2012). Kotler on Marketing. The Free Press.

Lankov, A., \& Kim, S. (2008). North Korean Market Vendors:
The rise of grassroots capitalists in a post-Stalinist society. Pacific Affairs, 81(1), 53-72.

Lankov, A. (2015). The real North Korea: Life and politics in the failed Stalinist utopia. London, England: Oxford.

Lankov, A. (2016, January). The resurgence of a market economy in North Korea (pp.1-17). Carnegie Moscow Center.

Nam, S. J. (2017). Exploring success factors of night markets: Utilizing the diamond model. International Journal of Industrial Distribution \& Business, 8(2), 33-38.

North Korean Economy Watch. (2019, November 24). No more beer commercials! Retrieved from http://www.nkeconwatch.com/2009/11/09/no-more-beercommercials.

North Korean Economy Watch. (2018). North Korean laws and regulations from consumer needs. Retrieved from https://www.nkeconwatch.com/category/advertising.

Park, H. (2018). The evolution of North Korean socialist economic system: From centrally planned system to the socialist enterprise responsibility system. Review of North Korean Studies, 21(2), 94-127.

Silberstein, B. K. (2019). Economic engagement with North Korea: Moving beyond Kaesong. Asian Perspective, 43(4), 721-736.

Tudor, D., \& Pearson, J. (2015). North Korea confidential: Private markets, fashion, trends, prison camps, dissenters and defectors.

Wainwright, T., Kibbler, E., Heikkila, J-P., \& Down, S. (2018). Elite entrepreneurship education: Translating ideas in North Korea. E\&PA: Economy and Space, 50(5), 1008-1026.

Xiang, Q. (2019). The black markets of North Korea. Modern Economy, 10, 1759-1768.

Yoo. S., Kang, M. S., \& Kim, M. (2019). Pioneering new markets: A case study of SevenBrau. Asia Marketing Journal, 20(4), 119.

Yoon, D. K. (2003). The constitution of North Korea: Its challenges and implications. Fordham International Law Journal, 27(4), 1289-1305. 